\title{
Oil Coking Prevention Using Electric Water Pump for Turbo-Charge Spark-Ignition Engines
}

\author{
Han-Ching Lin, ${ }^{1}$ Yen-Tso Chang, ${ }^{1}$ Go-Long Tsai, ${ }^{1}$ Dao-Ming Wang, \\ Feng-Chi Hsieh, ${ }^{1}$ and Jinn-Feng Jiang ${ }^{2}$ \\ ${ }^{1}$ Graduate Institute of Mechanical and Electrical Engineering, National Taipei University of Technology, Taipei 10626, Taiwan
}

${ }^{2}$ Metal Industries Research \& Development Centre, Taipei 10626, Taiwan

Correspondence should be addressed to Yen-Tso Chang; changyanzao@gmail.com

Received 28 May 2014; Accepted 11 August 2014; Published 27 August 2014

Academic Editor: Teen-Hang Meen

Copyright (C) 2014 Han-Ching Lin et al. This is an open access article distributed under the Creative Commons Attribution License, which permits unrestricted use, distribution, and reproduction in any medium, provided the original work is properly cited.

Turbocharger has been widely implemented for internal combustion engine to increase an engine's power output and reduce fuel consumption. However, its operating temperature would rise to $340^{\circ} \mathrm{C}$ when engine stalls. This higher temperature may results in bearing wear, run-out, and stick, due to oil coking and insufficient lubrication. In order to overcome these problems, this paper employs Electric Water Pump (EWP) to supply cool liquid to turbocharger actively when the engine stalls. The system layout, operating timing, and duration of EWP are investigated for obtaining optimal performance. The primarily experimental results show that the proposed layout and control strategy have a lower temperature of $100^{\circ} \mathrm{C}$ than the conventional temperature $225^{\circ} \mathrm{C}$.

\section{Introduction}

In order to reduce $\mathrm{CO}_{2}$ emission and fuel consumption, Turbocharged (T/C) technology has been widely implemented for reciprocating internal combustion engine [1,2]. Turbocharger driven by exhaust gas turbine can be used to increase charging air to cylinder and then produce more engine power output. Petitjean [3] obtained T/C engine of $30 \%$ downsizing that has the same performance as original nature-charged one without downsizing, and its fuel consumption can be reduced about 8 10\%. Lecointe and Monnier [4] also obtained that T/C used with downsizing, GDI, or variable valve timing technology has larger torque output in low engine speed, better fuel economy, and shorter light-off time of catalytic converter on a cold start.

Since more air charging would increase combustion power as well as combustion temperature, the temperature of turbocharger would also increase because it is driven by $800 \sim 900^{\circ} \mathrm{C}$ exhaust gas. Moreover, once the engine stalls, the temperature of turbocharger would significantly increase to $200^{\circ} \mathrm{C}$ due to uncirculated cooling fluid. This higher temperature may result in engine oil coking. Ribeiro et al.
[5] obtained the turbocharger bearing temperature increased from $95^{\circ} \mathrm{C}$ to $340^{\circ} \mathrm{C}$ within 40 seconds when engine stalls. After 90 seconds, the bearing temperature would decrease to about $135^{\circ} \mathrm{C}$, if the temperature of turbocharger is higher than $204^{\circ} \mathrm{C}$, which may cause damage to the oil quality. Moreover, if the temperature is over than $315^{\circ} \mathrm{C}$, it may cause oil coke. Honeywell [6] had tested the engine soak temperature, and the finding from the research is that booster ministry parts can reach as high as $260^{\circ} \mathrm{C} \sim 360^{\circ} \mathrm{C}$.

Thus, four conditions are required by Garrett [7] to prevent turbocharger from overheating: (1) avoid idle time more than 20 minutes; (2) have no coasting on a nature gear while stalling; (3) keep 3 5 minutes of idle time until lubricating oil pressure has been established on the engine; (4) keep $3 \sim 5$ minutes of idle time before stalling. However, it is very difficult to have a driver that follows these requirements. Ribeiro et al. [5] employed Electric Water Pump (EWP) to deal with the thermal problem of turbocharger when the engine stalls.

Comparing the EWP with conventional electric thermostat $[8,9]$, EWP can provide us with the following advantages: (1) provide active cooling and circulation for the T/C engine 
TABLE 1: Specification of target engine.

\begin{tabular}{lc}
\hline Type & Turbocharged Inline-4 \\
\hline Bore $\times$ stroke $[\mathrm{mm}]$ & $86 \times 94.6$ \\
Displacement $[\mathrm{L}]$ & 2.2 \\
Valve/cylinder & 4 \\
Compression ratio & $9.5: 1$ \\
Peak power $[\mathrm{kW} / \mathrm{rpm}]$ & $130 / 5000$ \\
Maximum torque $[\mathrm{Nm} / \mathrm{rpm}]$ & $275 / 3000$ \\
Emission standard & Euro 5 \\
\hline
\end{tabular}

TABLE 2: Environmental conditions of engine testing.

\begin{tabular}{ll}
\hline Conditions & Description \\
\hline \multirow{2}{*}{ Fuel } & Type: RON95 \\
& Temperature control: below $40^{\circ} \mathrm{C}$ \\
& Temperature measuring position: before fuel rail \\
\hline \multirow{2}{*}{ Engine oil } & Type: $10 \mathrm{~W} 40$ \\
& Temperature control: N/A \\
& Temperature measuring position: oil dish \\
\hline Liquid coolant & Concentration of antifreeze fluid: $60 \%$ \\
\hline \multirow{2}{*}{ Air charging } & Temperature control: $25 \pm 10^{\circ} \mathrm{C}$ \\
& Temperature measuring position: air box inlets \\
\hline
\end{tabular}

to prevent boiling over when the engine stalls; (2) supply more accurate engine temperature control to reduce engine friction losses; (3) reduce engine warm-up periods, as well as engine-out emissions. Riberio et al. [10] employed EWP to control engine coolant temperature for a $1.0 \mathrm{~L} 8 \mathrm{~V}$ engine. The experimental results show that coolant temperature as well as oil temperature of the targeted engine with EWP has faster warm-up period than conventional one about 1 and 3 minute(s), respectively.

Kawamoto et al. [11] applied the electronic pump technology to develop Hybrid Vehicle and lower fuel consumption by 1 to 4 percent.

The coolant flow into EWP needs to carry out the heat load can be obtained by using the following equation $[12,13]$ :

$$
\begin{gathered}
Q_{c}=\dot{m}_{c} C_{p}\left(T_{2}-T_{1}\right), \\
\dot{m}_{c}=\rho_{c} \dot{\forall},
\end{gathered}
$$

where $Q_{c}$ is heat rejection to coolant $(\mathrm{kJ} / \mathrm{s}), \dot{m}_{c}$ is coolant mass flow rate $(\mathrm{kg} / \mathrm{s}), C_{p}$ is specific heat capacity of the coolant $(\mathrm{kJ} / \mathrm{kg}-\mathrm{K}), T_{1}$ is temperature at engine inlet $(\mathrm{K}), T_{2}$ is temperature at engine outlet $(\mathrm{K}), \rho_{c}$ is coolant density $\left(\mathrm{kg} / \mathrm{m}^{3}\right)$, and $\dot{\forall}$ is coolant volume flow rate $\left(\mathrm{m}^{3} / \mathrm{s}\right)$.

The purpose of this paper is to employ EWP for supplying cooling liquid actively to turbocharger when engine stalls [14]. The EWP system layout, operating timing, and duration of EWP are investigated for obtaining optimal performance, that is, lowering the temperature of turbocharger. The remainder of this paper is organized as follows. For every layout and testing conditions of cooling system with EWP are introduced in Section 2, the relationship between original layout and the temperature of turbocharger are discussed in

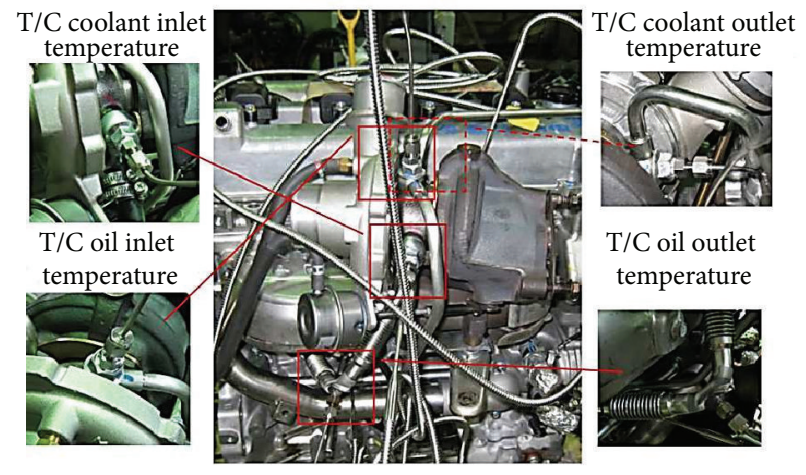

Figure 1: The locations of the four thermocouples.

Section 3. Secondly, the effects of different cooling layouts of EWP on the temperatures of turbocharger are evaluated using a dynamometer described in Section 4. Lastly, the conclusions are reached in Section 5.

\section{Experimental Setup}

2.1. Target Engine. A 4-cylinder 4-stroke 2.2 L turbo-charged spark-ignition engine was utilized in this paper, and a summary of its specifications is shown in Table 1.

A $240 \mathrm{~kW}$ Eddy current dynamometer was used to study the effect of different cooling layout on the coolant, oil, and turbocharger temperatures, with test environment settings as Table 2.

2.2. Location of Thermocouple. Four thermal couples were used to measured coolant inlet/outlet and oil inlet/outlet temperatures (see Figure 1) for analyzing thermal performance of the EWP.

2.3. Layout of Cooling System. In order to study the effect of different cooling layouts, three exiting vehicle cooling layouts, which consist of Mini Cooper, VW FSI, and VW TSI, were studied in this paper. The EWP of Mini Cooper is serially connected with inlet coolant pipe of T/C, and the coolant flows into the engine in the same direction. For the VW FSI, the EWP is serially connected to cooling outlet pipe of $\mathrm{T} / \mathrm{C}$ and operates 15 minutes after stalling. The direction of its coolant's flow was reversed to engine one. The EWP of VW TSI is serially connected to the cooling outlet pipe of T/C. Once the engine stalls, the EWP will start running for 8 minutes. Its coolant follows the direction same as that of engine one. After going through deep comparison mentioned above, each comparison result is shown in Table 3.

Two cooling system layouts, which consist of serial and parallel types, are proposed in this paper. For the proposed serial type of Figure 2, the EWP is serially connected to inlet cooling pipe of T/C. It is for the advantage that the modification on the system architecture is not significant. However, its cooling rate also cannot be changed due to inlet pipe size. For the proposed parallel type of Figure 3, since the EWP is connected to inlet cooling pipe of T/C in 
TABLE 3: EWP serial-type layouts.

\begin{tabular}{lll}
\hline T/C location & Flow direction \\
$\begin{array}{l}\text { Serially connecting inlet } \\
\text { coolant of } \mathrm{T} / \mathrm{C}\end{array}$ & The direction of engine rotation \\
$\begin{array}{l}\text { Serially connecting outlet } \\
\text { coolant of } \mathrm{T} / \mathrm{C}\end{array}$ & The reverse direction of engine rotation \\
$\begin{array}{l}\text { Serially connecting inlet } \\
\text { coolant of } \mathrm{T} / \mathrm{C}\end{array}$ & The direction of engine rotation
\end{tabular}

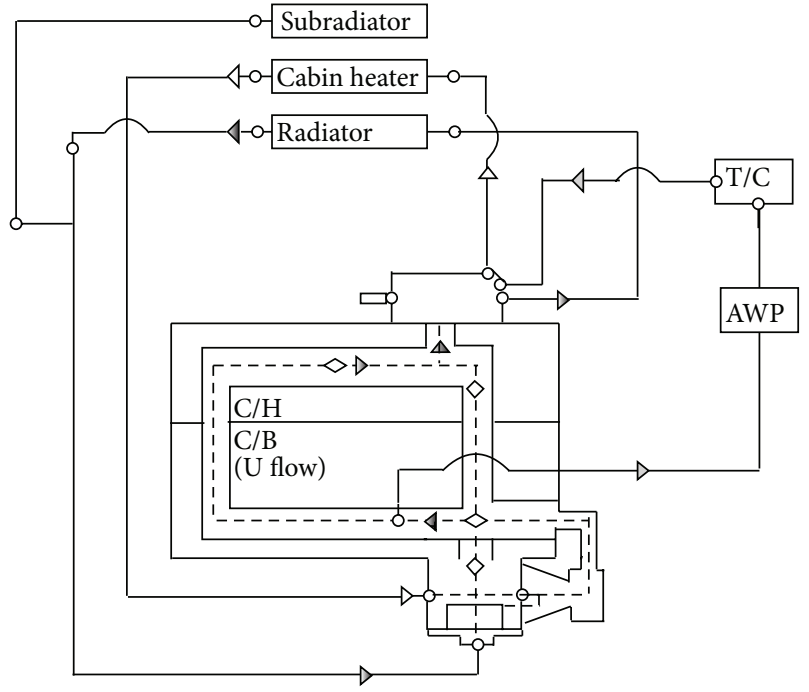

Figure 2: Proposed serial-type layout of EWP.

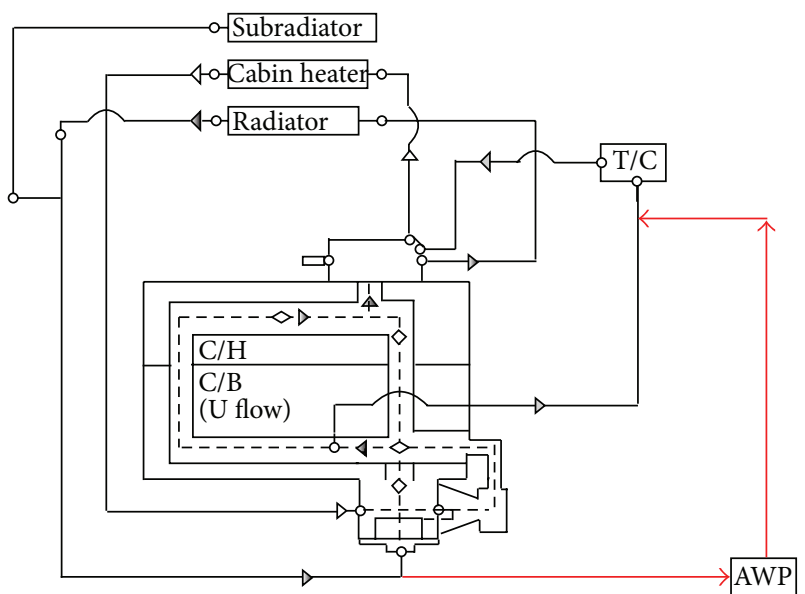

FIgURE 3: Proposed parallel-type layout of EWP. parallel through three link pipes, its cooling rate can be better controlled upon cooling efficiency than that of the serial type. However, the costs of parallel type would be increased by reason of more component parts.

2.4. Layout of Cooling System. The proposed system was evaluated in the dynamometer. First, the engine was operated at $5000 \mathrm{rpm}$ at wide open throttle. After engine coolant temperature rising to $105^{\circ} \mathrm{C}$, the tested engine would stall. Four thermocouples were then used to measure coolant temperatures of the turbocharger (see Figure 1). Different operation time for the EWP was used to evaluate thermal efficiency of the proposed system.

\section{Experimental Results of Original Layout}

3.1. Original Engine. The experimental results of the original engine are shown in Figure 4 . The maximum coolant outlet temperature of $\mathrm{T} / \mathrm{C}$ closes to $225^{\circ} \mathrm{C}$ when engine stalls after 5 minutes after running. After engine stalls for 41 minutes, the inlet and outlet coolant temperatures of $\mathrm{T} / \mathrm{C}$ are decreased to $100^{\circ} \mathrm{C}$ and $125^{\circ} \mathrm{C}$, respectively, since the measured temperature of original engine exceeds $225^{\circ} \mathrm{C}$, which may damage a turbocharger's bearings, as well as oil qualities.

3.2. Original Vehicle. In order to simplify the system development process, the original vehicle was employed to evaluate thermal difference between the original engine testing platform and vehicle. Figures 5 and 6 present experimentally measured temperature results for the original vehicle with different velocities before resulting in a stalling engine. Figure 5 shows that the vehicle drives $40 \mathrm{~km} / \mathrm{hr}$ before stall; the maximum temperature increases up to $214^{\circ} \mathrm{C}$ when the vehicle stalls after 6 minutes. After stalling for 69 minutes, the inlet and outlet coolant temperatures of $\mathrm{T} / \mathrm{C}$ are decreased to $100^{\circ} \mathrm{C}$ and $125^{\circ} \mathrm{C}$, respectively.

If the vehicle is moving at a speed of $120 \mathrm{~km} / \mathrm{hr}$ before stall, the maximum temperature is increased to $222^{\circ} \mathrm{C}$ when vehicle stalls after 6 minutes, as shown in Figure 6. After 

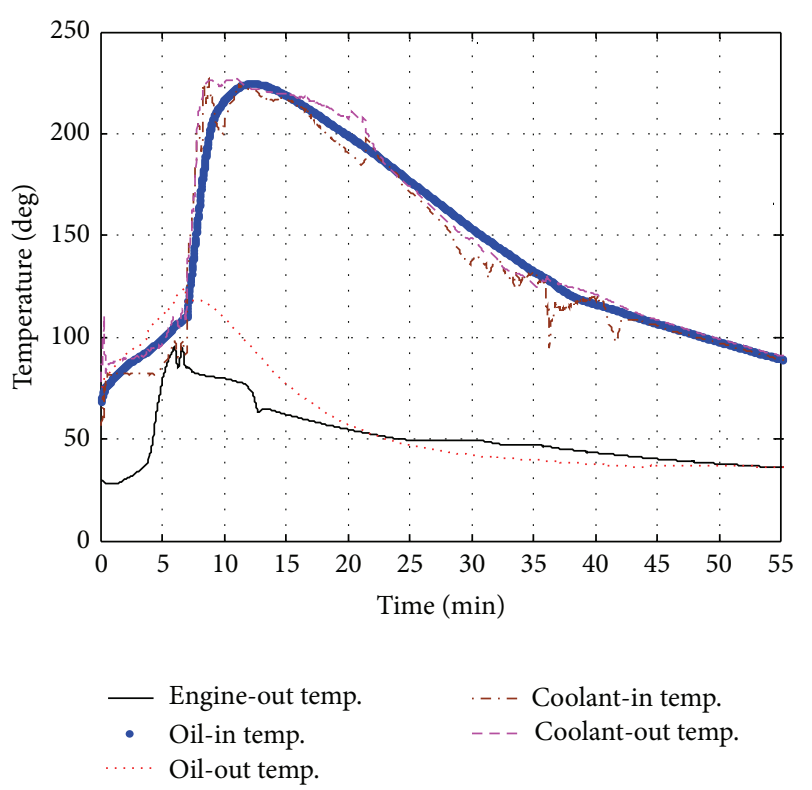

FIGURE 4: Experimental results of T/C temperatures for the original engine.

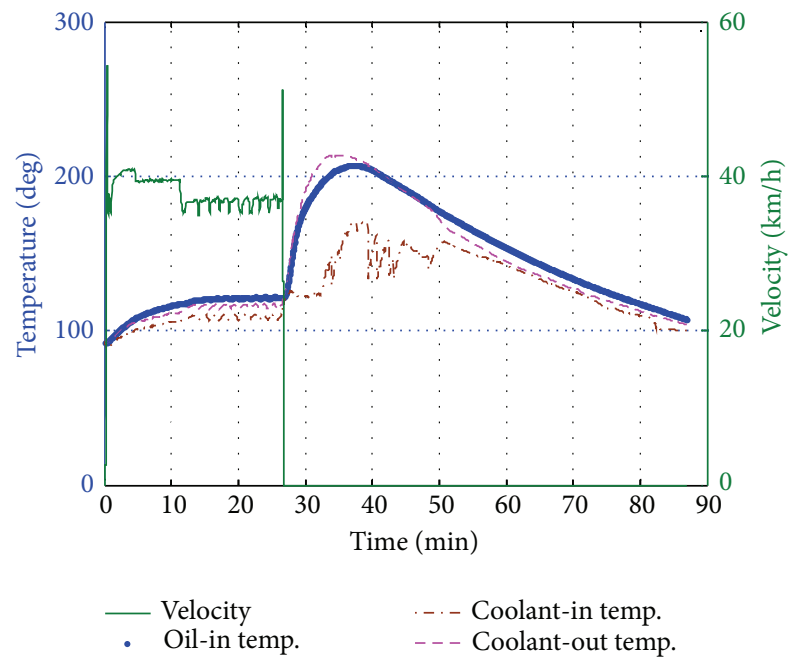

FIGURE 5: Original vehicle moving with a speed of $40 \mathrm{~km} / \mathrm{hr}$ before stall.

stalling for 73 minutes, the coolant inlet and outlet temperatures of $\mathrm{T} / \mathrm{C}$ drop to $100^{\circ} \mathrm{C}$ and $125^{\circ} \mathrm{C}$, respectively.

After comparing the experimental results in the case of the original vehicle with the results of engine one, both experimental results show they have similar maximum temperature and trend characteristics. Thus, the results obtained on the engine testing platform can be used to represent the vehicle one.

\section{Experimental Results of Proposed Layout}

4.1. Proposed Serial-Type Layout. Since the flow rate of serialtype EWP is limited because coolant inlet pipe diameter of turbocharger cannot be changed, different running time

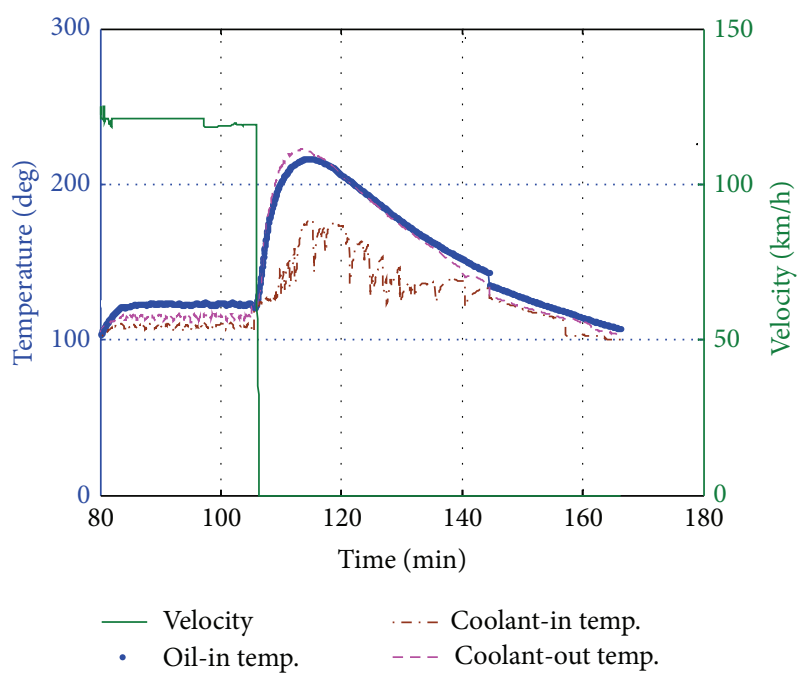

FIGURE 6: Original vehicle moving with a speed of $120 \mathrm{~km} / \mathrm{hr}$ before stall.

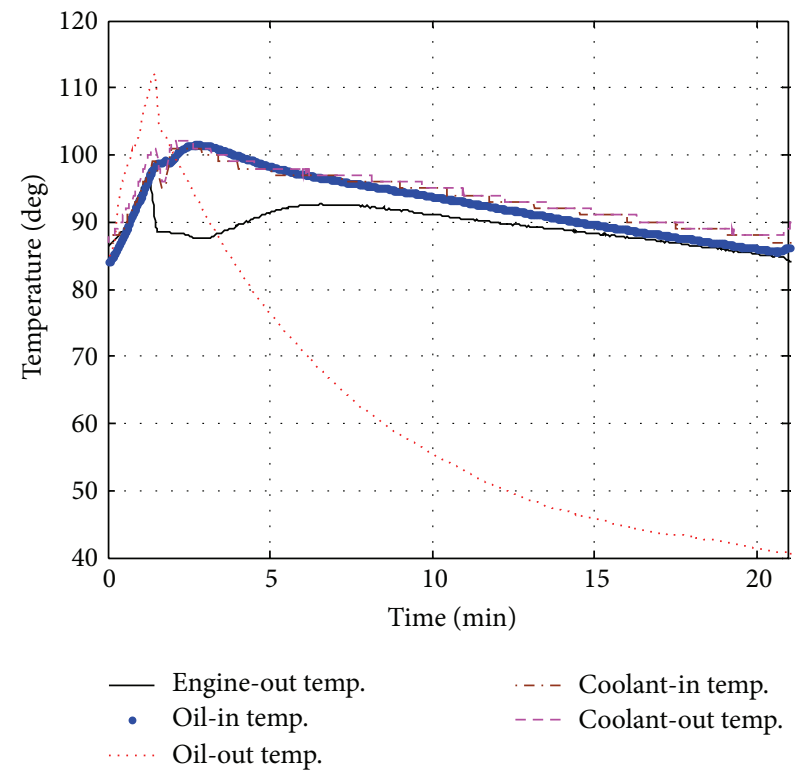

FIGURE 7: Proposed serial type with keep running.

is employed to evaluate thermal characteristics. The flow rate of serial type adjusts using original engine one up to $840 \mathrm{~L} / \mathrm{H}$ (liter/hour). Figure 7 shows the experimental results of proposed serial-type layout while keeping EWP running. The tested engine stalls after the engine coolant outlet temperature has risen to $105^{\circ} \mathrm{C}$; the proposed serial-type EWP starts running then. Since the liquid coolant mixtures of turbocharger can keep running using EWP, the system temperatures would increase, and coolant inlet temperature of turbocharger would dip below $100^{\circ} \mathrm{C}$ after 2 minutes.

However, if the EWP is not kept running, the coolant outlet temperature of turbocharger would reincrease from $87^{\circ} \mathrm{C}$ to $101^{\circ} \mathrm{C}$ within 5 minutes after EWP stops running, as shown in Figure 8. Moreover, if the running time was reduced 


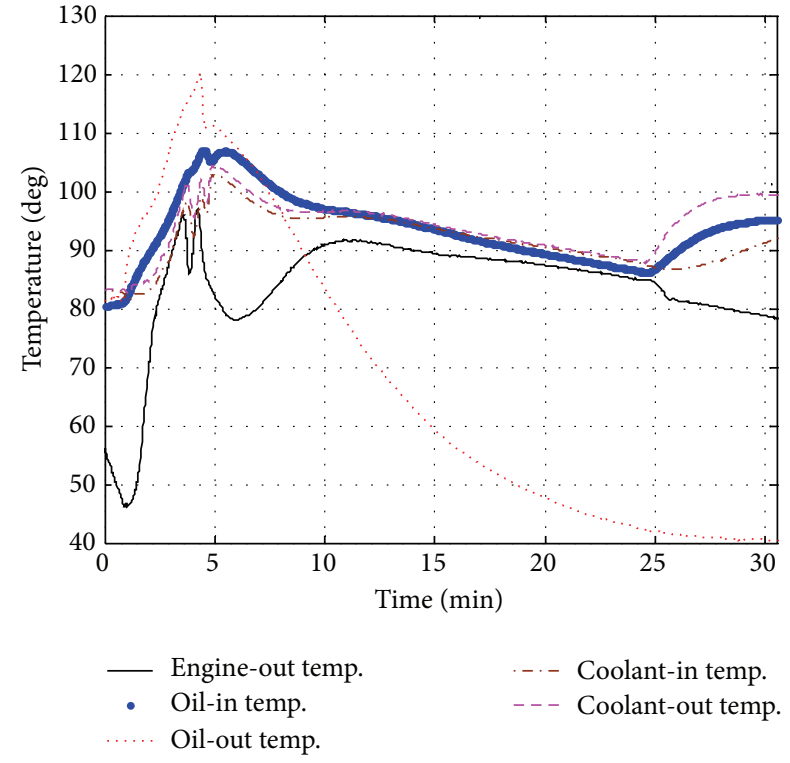

FIGURE 8: Proposed serial type with a running time of 20 minutes.

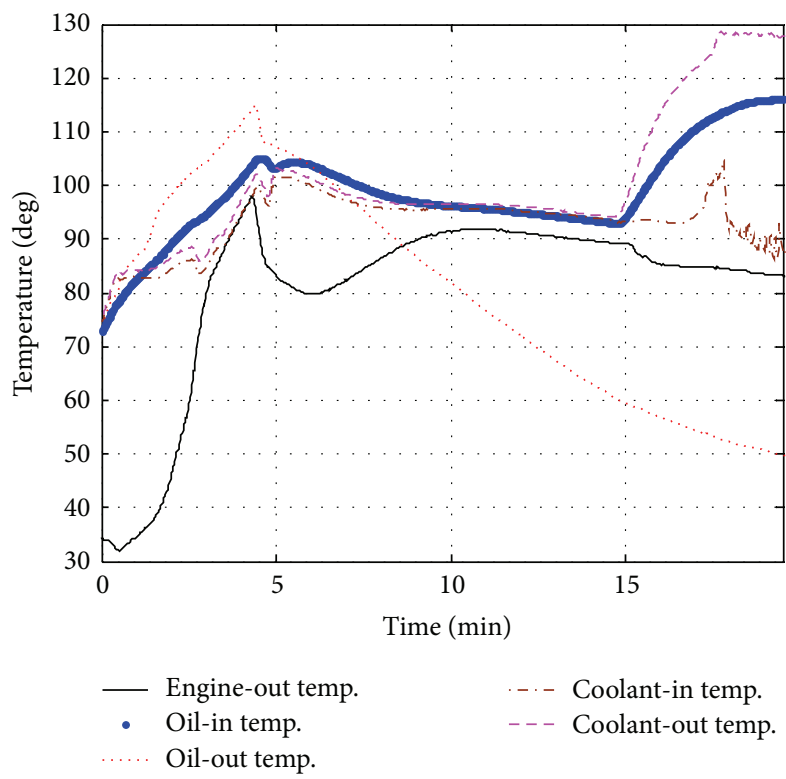

FIgURe 9: Proposed serial type with a running time of 10 minutes.

to 10 minutes, the coolant outlet temperature of turbocharger would reincrease to $128^{\circ} \mathrm{C}$ within 3 minutes, as shown in Figure 9.

4.2. Proposed Parallel-Type Layout. For the parallel-type layout, because the liquid coolant mixtures directly come from radiator, the flow rate of EWP can be adjusted according to the following system requirements. The flow rates of $1080,1200,1380$, and $1569 \mathrm{~L} / \mathrm{H}$ with different running time were used to evaluate thermal characteristics. Figures 10 and 11 show the experimental results of EWP with flow rate $1080 \mathrm{~L} / \mathrm{H}$ and running time of 5 and 10 minutes, respectively. If the running time of EWP was set to be 5 minutes, the

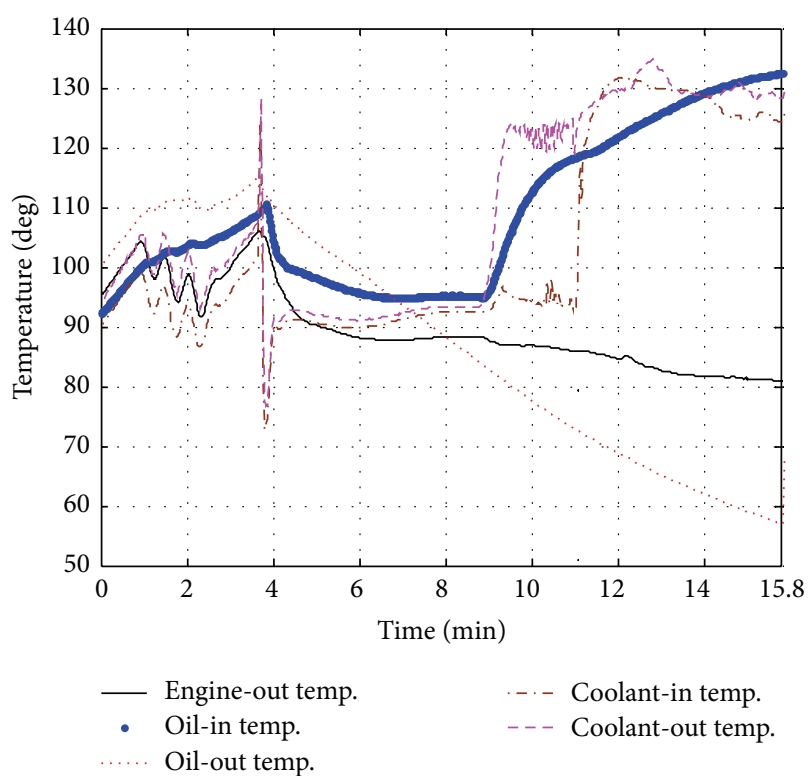

FIGURE 10: Proposed parallel type with flow rate $1080 \mathrm{~L} / \mathrm{H}$ and a running time of 5 minutes.

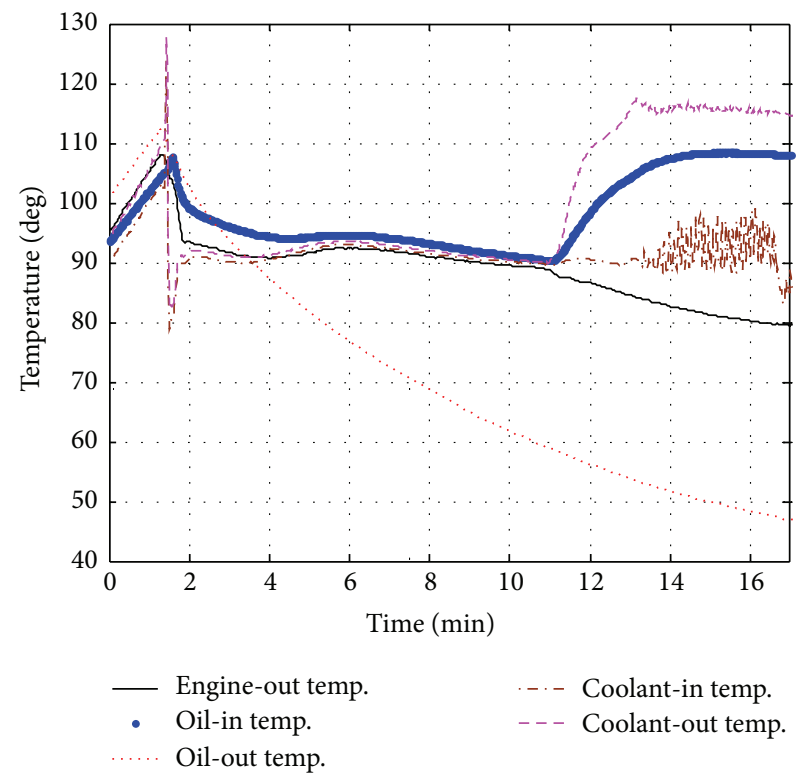

FIgURE 11: Proposed parallel type with flow rate $1080 \mathrm{~L} / \mathrm{H}$ and a running time of 10 minutes.

coolant outlet temperature of turbocharger would reincrease from $96^{\circ} \mathrm{C}$ to $134.8^{\circ} \mathrm{C}$ within 4 minutes. Once the running time increases to 10 minutes, the maximum coolant outlet temperature of turbocharger reduces to $117.5^{\circ} \mathrm{C}$.

If the flow rate increases to $1200 \mathrm{~L} / \mathrm{H}$, the experimental results of running time of 5,7 , and 10 minutes are shown in Figures 12,13 , and 14 , respectively. If the running time is 5 minutes (see Figure 12), the maximum coolant temperature would be $128.4^{\circ} \mathrm{C}$, which is lower than the results in Figure 10 as the flow rate increases. Furthermore, if the running time 


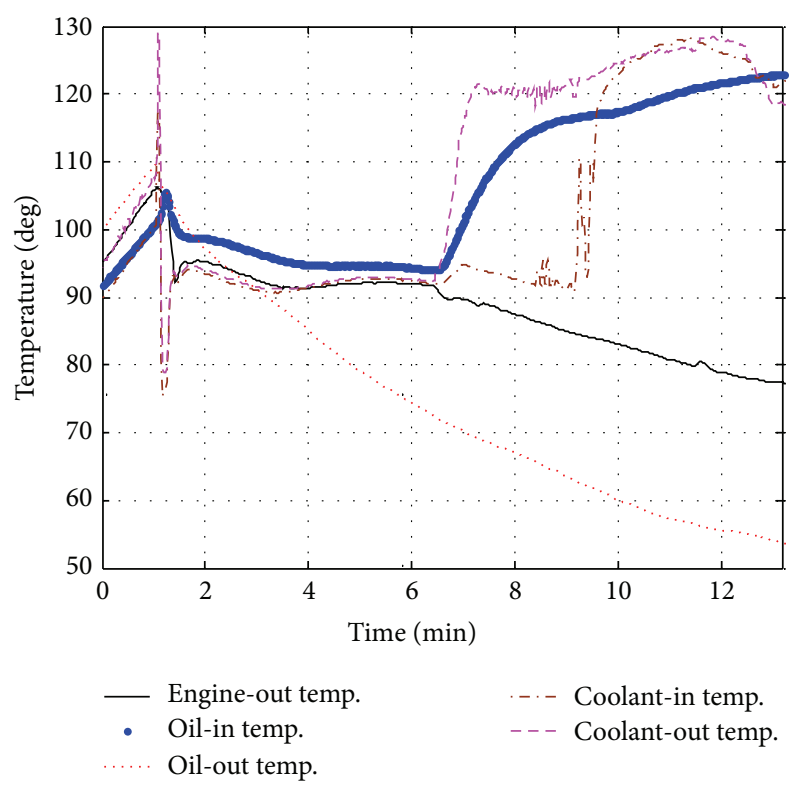

Figure 12: Proposed parallel type with flow rate $1200 \mathrm{~L} / \mathrm{H}$ and a running time of 5 minutes.

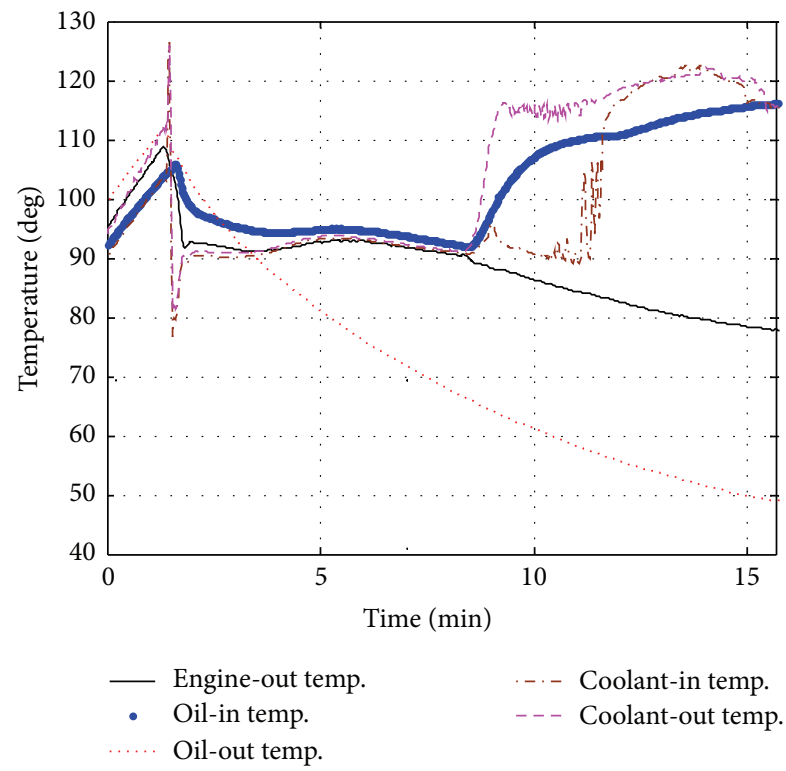

FIGURE 13: Proposed parallel type with flow rate $1200 \mathrm{~L} / \mathrm{H}$ and a running time of 7 minutes.

increases to 7 or 10 minutes, the maximum temperature could reduce to $122.6^{\circ} \mathrm{C}$ and $111.9^{\circ} \mathrm{C}$, as shown in Figures 13 and 14 , respectively.

If we further increase the flow rate to $1380 \mathrm{~L} / \mathrm{H}$ and $1560 \mathrm{~L} / \mathrm{H}$ and keep the running time of 5 minutes, in Figures 15 and 16 , the maximum coolant temperatures of $127.7^{\circ} \mathrm{C}$ and $128.6^{\circ} \mathrm{C}$ are similar.

The comparison of different running time and flow rate for both parallel- and serial-type layouts are shown in Table 4. The longer the running time is, the lower the maximum coolant temperature is. However, the maximum coolant

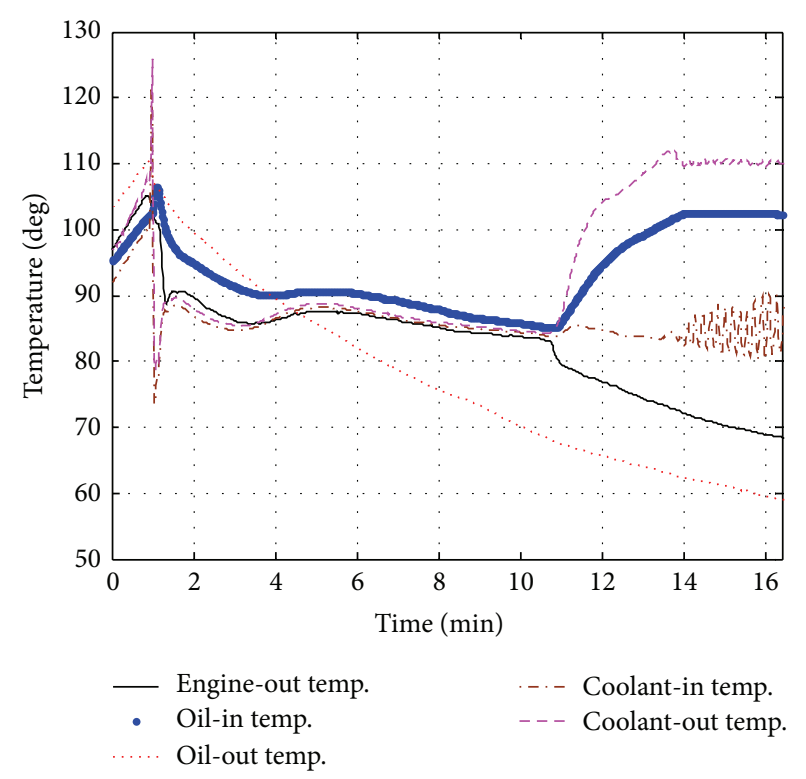

FIGURE 14: Proposed parallel type with flow rate $1200 \mathrm{~L} / \mathrm{H}$ and a running time of 10 minutes.

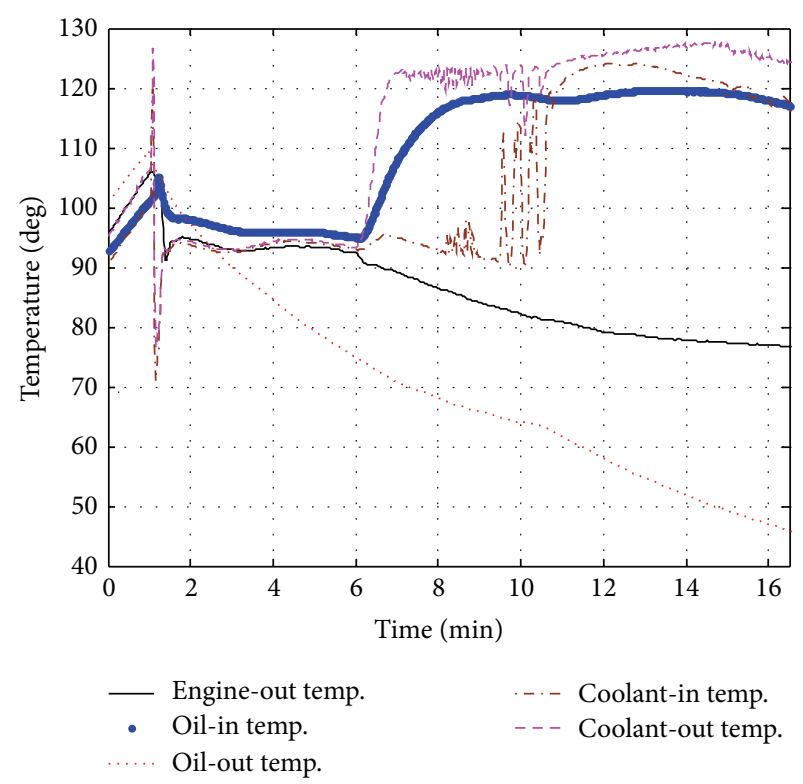

Figure 15: Proposed parallel type with flow rate $1380 \mathrm{~L} / \mathrm{H}$ and a running time of 5 minutes.

temperature would not reduce by increasing the flow rate. The only effective flow rate would be in the cool-down duration when EWP is running. Besides, the higher flow rate would increase electricityconsumption. Thus, the optimal flow rate would be $1200 \mathrm{~L} / \mathrm{H}$, because it has lower maximum coolant temperature without higher electricity consumption. Moreover, if we compare the serial-type with parallel one using the same running time, the maximum temperature of serial-type layout is $128^{\circ} \mathrm{C}$; it is significantly higher than that of the parallel one, even adopting the lowest flow rate. 


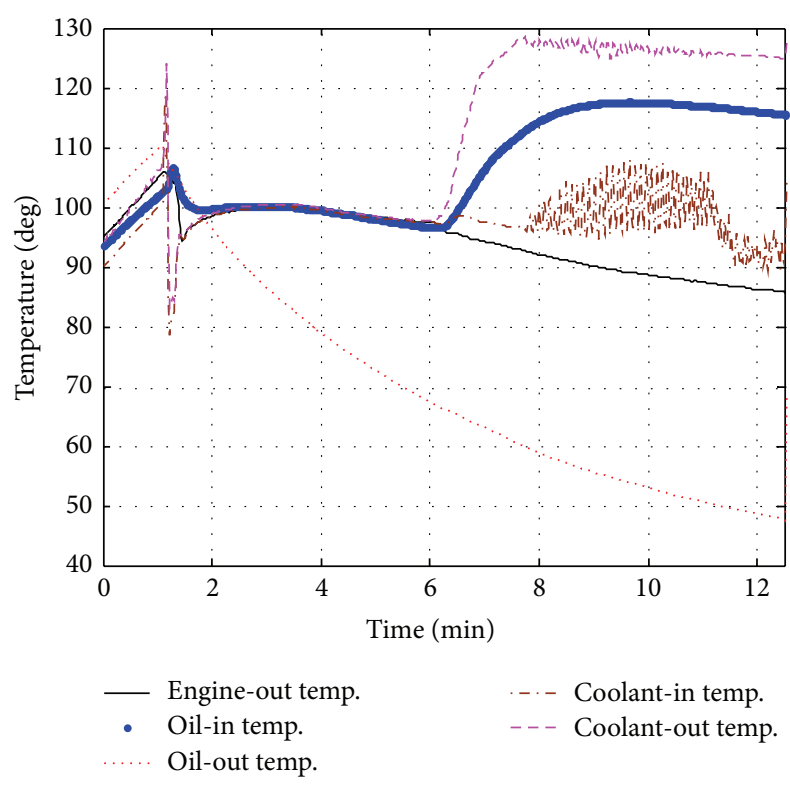

FIGURE 16: Proposed parallel type with flow rate $1560 \mathrm{~L} / \mathrm{H}$ and a running time of 5 minutes.

TABLE 4: Comparison of different running time and flow rate.

\begin{tabular}{ccc}
\hline Flow rate & $\begin{array}{c}\text { EWP running time } \\
\text { (minute) }\end{array}$ & $\begin{array}{c}\text { Outlet of T/C } \\
\text { temperature }\end{array}$ \\
\hline \multirow{2}{*}{$1080 \mathrm{~L} / \mathrm{H}$} & 5 & 134.8 \\
& 7 & - \\
& 10 & 117.5 \\
\hline \multirow{2}{*}{$1200 \mathrm{~L} / \mathrm{H}$} & 5 & 128.5 \\
& 7 & 122.6 \\
& 10 & 111.9 \\
\hline \multirow{3}{*}{$1380 \mathrm{~L} / \mathrm{H}$} & 5 & 127.7 \\
& 7 & - \\
$1560 \mathrm{~L} / \mathrm{H}$ & 10 & - \\
& 5 & 128.6 \\
\hline
\end{tabular}

\section{Conclusion}

The purpose of this paper is to evaluate thermal characteristic of turbocharger when engine stalls. The experimental results show that the maximum coolant temperature of turbocharger rises to $225^{\circ} \mathrm{C}$, which may cause engine bearing and oil quality damage. Different EWP's cooling layout types, which consist of serial and parallel types, are then implemented to reduce the maximum temperature. Firstly, an engine testing platform was established to evaluate thermal characteristics, and experimental results show that it can be used to represent the thermal characteristics of turbocharger in the actual vehicle. Different flow rates of 1080, 1200, 1380, and $1569 \mathrm{~L} / \mathrm{H}$, with different running time, were used to evaluate thermal characteristics of parallel-type. Due to the limitation of coolant inlet pipe diameter of turbocharger, the flow rate of serial-type EWP cannot be adjusted. The experimental results show that the running time of serial-type layout is the same with the Parallel, its maximum temperature is $128^{\circ} \mathrm{C}$, and would be significantly higher than that of the parallel one, even using the lowest flow rate. Therefore, the proposed parallel-type layout shows the thermal characteristics of efficiency improvement. Furthermore, the experimental results of parallel-type show that the longer the running time is, the lower the maximum coolant temperature is. However, the maximum coolant temperature would not be affected by flow rate. The only effective flow rate would occur in the cooldown time when the EWP is running. Besides, the more flow rate would increase electricity consumption. Thus, the optimal flow rate would be $1200 \mathrm{~L} / \mathrm{H}$, because it has lower maximum coolant temperature without higher electricity consumption.

\section{Conflict of Interests}

The authors declare that there is no conflict of interests regarding the publication of this paper.

\section{References}

[1] P. Sunil, "Turbocharging and oil techniques in light motor vehicles," Research Journal of Recent Sciences, vol. 1, no. 1, pp. 60-65, 2012.

[2] J. B. Heywood, Internal Combustion Engine Fundamentals, McGraw-Hill, New York, NY, USA, 1988.

[3] H. Petitjean, "Advanced gasoline engine turbocharging technology for fuel economy improvements," SAE Paper 2004-01-0988, 2004.

[4] B. Lecointe and G. Monnier, "Downsizing a Gasoline Engine Using Turbocharging with Direct Injection," SAE Paper, 200301-0542, 2003.

[5] E. G. Ribeiro, W. B. Melo, and A. P. A. Fiho, "Application of electric oil pump on automotive systems," SAE Paper 2005-014086, 2005.

[6] "Advanced turbo-charging research and development," Tech. Rep. DE-FC26-06NT42873, The U.S. Department of Energy, 2008.

[7] Garrett Turbo User Guide, Honeywell International Inc.

[8] R. Squarcini, M. Gasperini, G. Peroni, G. Simon, and M. Olivetti, "EWP thermal management," ATA-Ingegneria Dell'utoveicolo, vol. 64 , no. 5/6, 2011.

[9] C. J. Brace, H. Burnham-Slipper, R. S. Wijetunge, N. D. Vaughan, K. Wright, and D. Blight, "Integrated cooling systems for passenger vehicles," SAE Technical Paper 2001-01-1248, 2001.

[10] E. G. Riberio, A. P. D. A. Fiho, and J. L. D. C. Meira, "Electric water pump for engine cooling," SAE Paper, 2007-01-2785, 2007.

[11] N. Kawamoto, K. Naiki, T. Kawai, T. Shikida, and M. Tomatsuri, "Development of new 1.8-liter engine for hybrid," SAE Paper 2009-01-1061, 2009.

[12] R. F. Crook, 14 Rules for Improving Engine Cooling Systems Capability in High-Performance Automobiles, USA National Automotive Radiator Association, Transpro, 2007. 
[13] L. A. Jiear, "Cooling system analysis," Final Thesis Report, University of New South Wales at the Australian Defence Force Academy, 2008.

[14] F. Westin, J. Rosenqvist, and H.-E. Angstrom, "Heat losses from the turbine of a turbocharged si-engine-measurements and simulation," SAE Paper 2004-01-0996, 2004. 


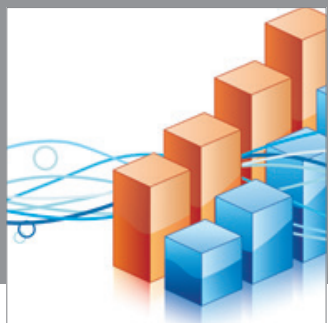

Advances in

Operations Research

mansans

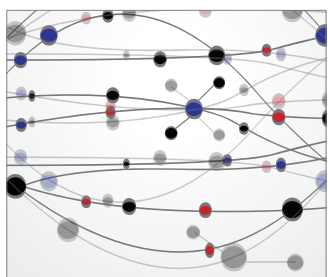

The Scientific World Journal
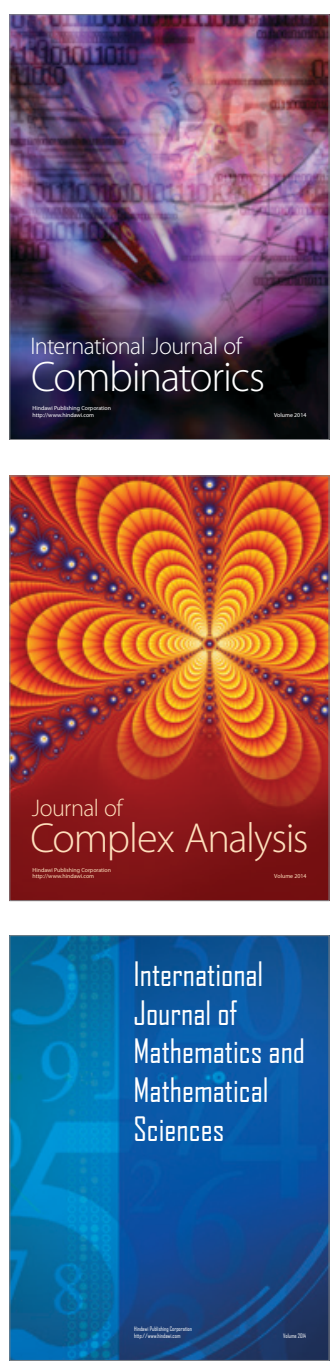
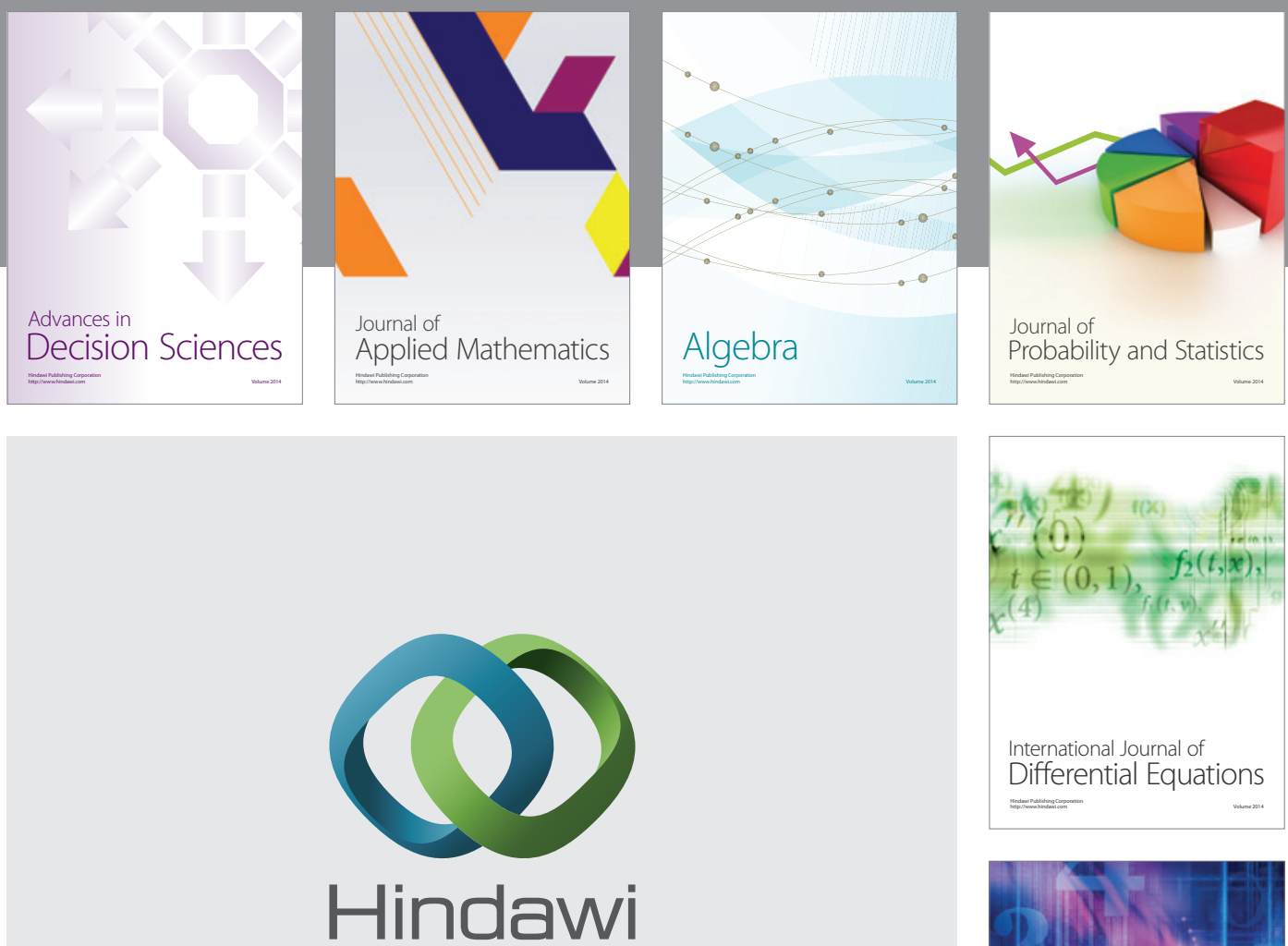

Submit your manuscripts at http://www.hindawi.com
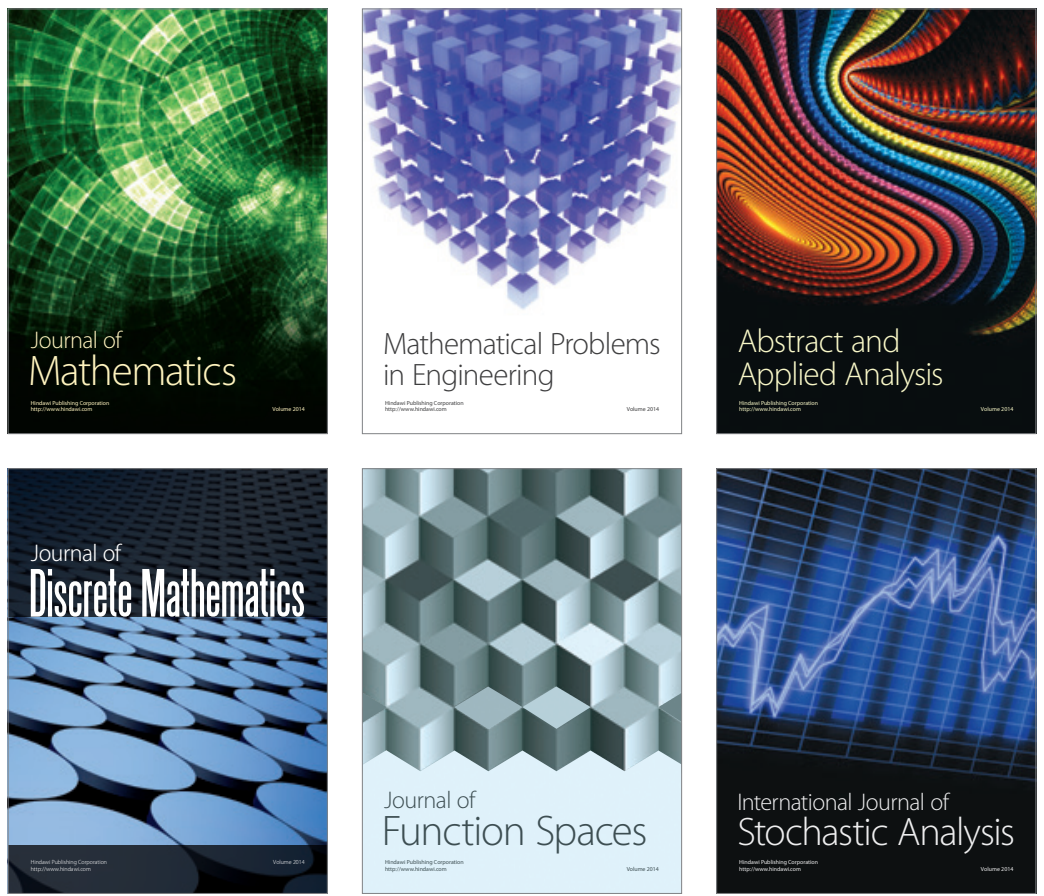

Journal of

Function Spaces

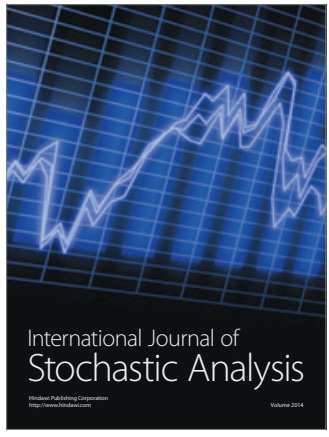

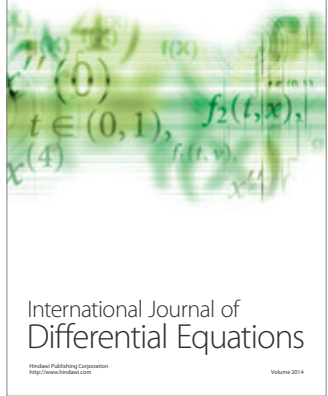
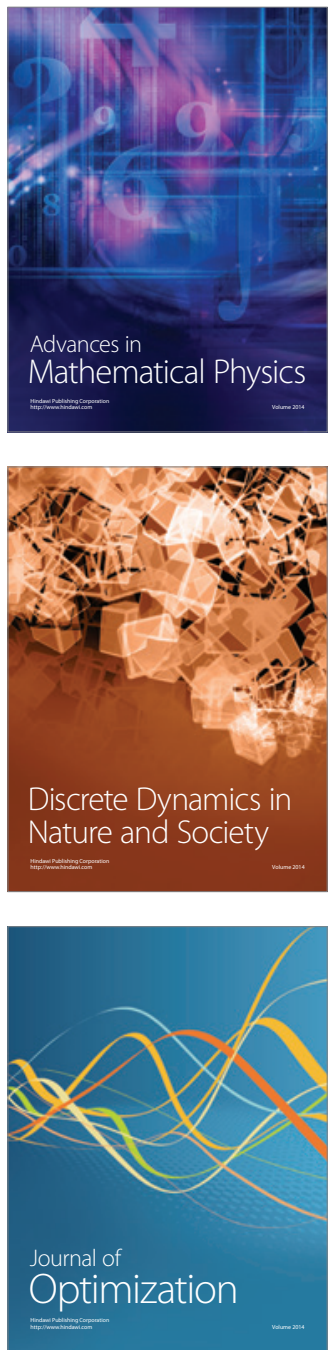